\title{
Sosialisasi dan Pemberian Vaksin dalam Rangka Menghadapi Kuliah Tatap Muka di ITKES Muhammadiyah Sidrap
}

\author{
Wilda Rezki Pratiwi*1, Nur Laela², Edy Arsyad ${ }^{3}$, Resmawati ${ }^{4}$ \\ 1,2,3,4Fakultas Keperawatan dan Kebidanan, ITKES Muhammadiyah Sidrap, Indonesia \\ *e-mail: wildapratiwi06@gmail.com ${ }^{1}{ }_{2}$ elha1338@gmail.com ${ }^{2}{ }_{2}$ edyarsyad01@gmail.com ${ }^{3}$
}

\begin{abstract}
Abstrak
Wabah Corona virus disease 2019 (COVID-19) memberikan tantangan bagi lembaga pendidikan, khususnya Perguruan Tinggi. Bentuk perkuliahan yang dapat dijadikan solusi dalam masa pandemi COVID19 adalah pembelajaran daring. Melalui Kementerian Pendidikan dan Kebudayaan Pemerintah telah melarang perguruan tinggi untuk melaksanakan perkuliahan tatap muka (konvensional). Salah satu upaya untuk memutus mata rantai penyebaran pandemic COVID-19 yaitu dengan pemberian vaksin. maka dari itu perlu adanya wadah untuk layanan pemberian vaksin. Perguruan Tinggi Institut Teknologi Kesehatan dan Sains Muhammadiyah Sidrap merupakan salah satu institusi yang bergerak dibidang kesehatan ikut mendukung program pemerintah Indonesia. Metode kegiatan: analisis kebutuhan, sosialisasi dan vaksinasi. Hasil dari kegiatan ini yaitu: bahwa Tenaga Pendidik dan kependidikan sebagai salah satu penggerak kemajuan suatu bangsa telah dipersiapkan terlebih dahulu untuk kembali mengadakan pembelajaran tatap muka sesuai dengan anjuran pemerintah.
\end{abstract}

Kata kunci: Sosialisasi, Vaksinasi, Kuliah Tatap Muka

\begin{abstract}
The Coronavirus disease 2019 (COVID-19) outbreak poses challenges for educational institutions, especially universities. The form of lectures that can be used as a solution during the COVID-19 pandemic is online learning. Through the Ministry of Education and Culture, the Government has prohibited universities from conducting face-to-face (conventional) lectures. One of the efforts to break the chain of the spread of the COVID-19 pandemic is by giving vaccines. Therefore, there is a need for a container for vaccine delivery services. The Muhammadiyah Sidrap Institute of Health Technology and Science College is one of the institutions engaged in the health sector that supports the Indonesian government's programs. Activity method: needs analysis, socialization and vaccination The results of this activity are: that educators and education as one of the drivers of the progress of a nation have been prepared in advance to return to holding face-to-face learning in accordance with government recommendations.
\end{abstract}

Keywords: Socialization, Vaccination, Face-to-Face Lectures

\section{PENDAHULUAN}

Saat ini Corona masih menjadi isu dikalangan masyarakat yang diberitakan secara masif. Kebijakan pemerintah pada saat pandemi yang lebih dikenal dengan Pembatasan Sosial Berskala Besar (PSBB) menjadikan segala aktivitas masyarakat di luar harus dihentikan sampai pandemi mereda. Kebijakan pemerintah lainya yaitu penerapan pembelajaran yang dilakukan oleh siswa secara daring (dalam jaringan) atau online.

Wabah Coronavirus disease 2019 (COVID-19) memberikan tantangan bagi lembaga pendidikan, khususnya Perguruan Tinggi. Melalui Kementerian Pendidikan dan Kebudayaan Pemerintah telah melarang perguruan tinggi untuk melaksanakan perkuliahan tatap muka (konvensional) dan memerintahkan untuk menyelenggarakan perkuliahan atau pembelajaran secara daring (Surat Edaran Kemendikbud Dikti No. 1 tahun 2020). Perguruan tinggi dituntut untuk dapat menyelenggarakan pembelajaran secara daring (Firman \& Rahayu, 2020). Bentuk perkuliahan yang dapat dijadikan solusi dalam masa pandemi COVID-19 adalah pembelajaran daring. Pembelajaran daring merupakan inovasi pendidikan untuk menjawab tantangan akan ketersediaan sumber belajar yang variatif. Keberhasilan dari suatu model ataupun media pembelajaran tergantung dari karakteristik peserta didiknya (Dewi, 2020).

Di masa pandemi COVID-19 diperlukan sistem kekebalan yang efektif untuk sebagai langkah sistem kesehatan yang efektif. Banyaknya hasil penelitian yang mengembangkan vaksin 
merupakan langkah yang efektif memerangi penyakit coronavirus 2019 (Astuti, 2021). Topik vaksinasi merupakan salah satu tema yang sering diperbincangkan di kalangan masyarakat. Hasil penelitian Winda Yulita 2021 menyatakan pendapat masyarakat Indonesia khususnya pengguna media sosial Twitter, rata-rata memberikan respon positif terkait adanya kebijakan vaksinasi COVID-19 di Indonesia (Yulita, 2021).

Di era new normal seperti sekarang ini dunia pendidikan dituntut untuk melakukan pembelajaran tatap muka. Tak bisa dipungkiri bahwa hampir $100 \%$ peserta didik terkena dampak akibat dari pandemi COVID-19. Salah satu upaya untuk memutus mata rantai penyebaran pandemic COVID-19 yaitu dengan pemberian vaksin (Lamirin, 2021) maka dari itu perlu adanya wadah untuk layanan pemberian vaksin. Perguruan Tinggi Institut Teknologi Kesehatan dan Sains Muhammadiyah Sidrap merupakan salah satu institusi yang bergerak dibidang kesehatan ikut mendukung program pemerintah Indonesia.

Dalam pengabdian masyarakat (Lamirin, et al., 2021), hasil daripada program vaksinasi ini adalah bahwa Tenaga Pendidik dan kependidikan sebagai salah satu penggerak kemajuan suatu bangsa telah dipersiapkan terlebih dahulu untuk kembali mengadakan pembelajaran tatap muka sesuai dengan anjuran pemerintah. Hasil pengabdian lain dari (Nurdiana, dkk., 2021) didapat peningkatan pengetahuan peserta seputar efikasi dan efektivitas vaksin COVID-19, serta ditemukannya perubahan sikap peserta tentang kesiapan diri untuk mendapatkan vaksinasi COVID-19 dari tidak mau dan ragu menjadi bersedia.

Tujuan Pengabdian ini adalah memberikan pemahaman mengenai pentingnya vaksinasi COVID-19 dimasa pandemi saat ini dan memberikan layanan vaksinasi COVID-19 bagi peserta didik, tenaga pendidik dan kependidikan di Institut Teknologi Kesehatan dan Sains Muhammadiyah Sidrap.

\section{METODE}

Program kegiatan ini dilakukan dengan metode sebagai berikut:

1. Analisis Kebutuhan

Didalam proses pelaksanaan kegiatan, dilakukan persiapan administrasi, pendataan peserta vaksinasi, mengirim surat permohonan vaksinasi COVID-19 kepada Satgas Covid Kabupaten Sidrap, persiapan lokasi pelaksanaan program kegiatan.

2. Sosialisasi

Kegiatan sosialisasi tentang pentingnya vaksinasi COVID-19, serta manfaat dan dampak dari vaksinasi COVID-19 kepada peserta penerima vaksin agar setiap program pelaksanaan vaksinasi terlaksana dengan baik dan tetap memenuhi protokol kesehatan yang dianjurkan oleh Pemerintah selama pandemic COVID-19.

3. Vaksinasi

Vaksinasi yang sejak awal ditunjukan kepada tenaga pendidikan dan kependidikan akan dilaksanakan sebagaimana procedural medis dengan terlebih dahulu dilakukan screening kesehatan calon penerima vaksin melalui angket pemeriksaan dan pemeriksaan tanda-tanda vital (nadi, suhu, pernapasan, tekanan darah). Hal ini dilakukan untuk mencegah efek samping daripada vaksin COVID-19 yang telah disuntikan pada tubuh peserta.

\section{HASIL DAN PEMBAHASAN}

ITKES Muhammadiyah Sidrap merupakan Perguruan Tinggi Pendidikan di bidang kesehatan yang terdiri dari 2 Fakultas yaitu Fakultas Keperawatan dan Kebidanan dan Fakultas Teknologi dan Sains. Pelaksanaan kegiatan program dimulai dengan surat permohonan vaksinasi kepada satgas Covid Kabupaten Sidrap Bapak DR. Ishak Kenre, SKM., M. Kes. Persiapan lokasi kegiatan telah disiapkan dengan tetap menjalankan protokol kesehatan yang dianjurkan oleh Pemerintah. Jumlah Peserta yang mengikuti vaksinasi terdiri dari 48 tenaga kependidikan, mahasiswa 468 peserta dan dari masyarakat sekitar 290 orang peserta dengan memperhatikan prosedur sebagai berikut: Membawa fotocopy Kartu Tanda Penduduk (KTP), Kartu Keluarga, Kartu Mahasiswa serta mematuhi protokol kesehatan. 


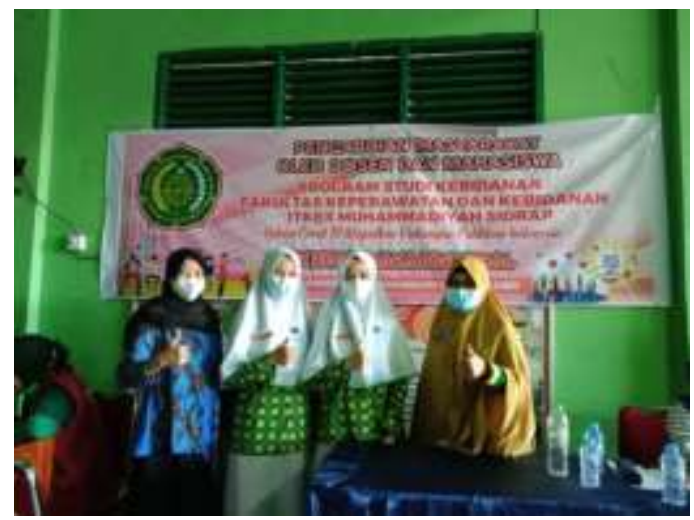

Gambar 1. Foto Bersama Mahasiswa dan TIM Abdimas

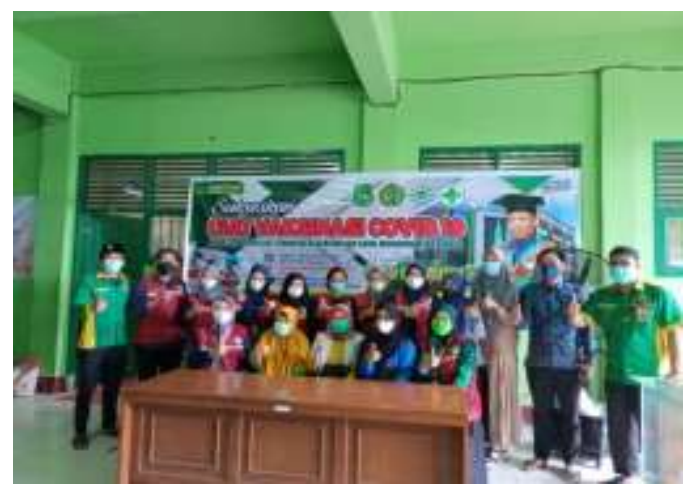

Gambar 2. Foto Bersama dengan TIM Vaksinasi Puskesmas

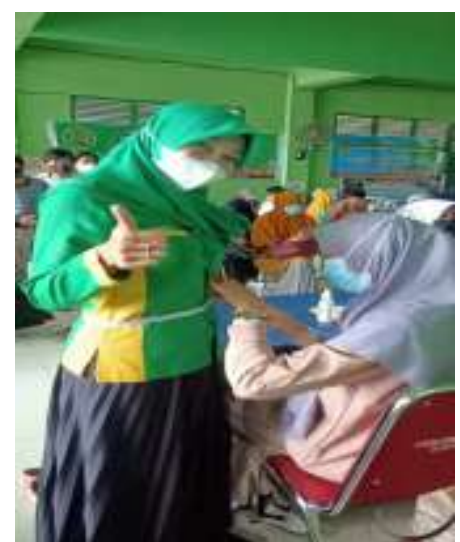

Gambar 3. Foto Pelaksanaan Kegiatan (Meja 2)

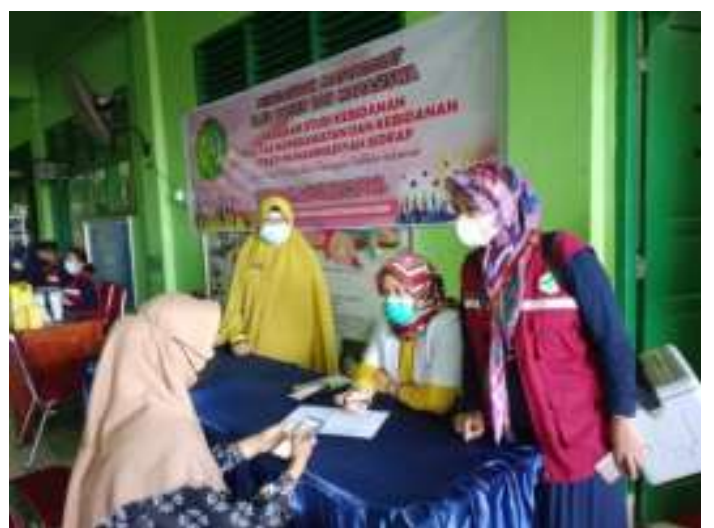

Gambar 4. Foto Wawancara peserta Vaksin 
Kegiatan kemudian dilanjutkan dengan melakukan sosialisasi kepada semua peserta yang akan melakukan vaksinasi. Vaksin yang digunakan adalah jenis Sinovac dan Moderna.

Kegiatan tahap Pelaksanan kegiatan dilakukan pada hari Sabtu, 11 September 2021 pada pukul 08.00 s/d 16.30 Wita di Aula Sang Pencerah. Peserta vaksin sangat antusias. Tim pengabdian masyarakat melakukan penyaringan pada peserta yang akan melewati setiap meja pos vaksinasi. Kegiatan vaksinasi COVID-19 tahap kedua akan dilaksanakan pada hari Sabtu, 09 Oktober 2021 di Laboratorium ITKES Muhammadiyah Sidrap. Kegiatan Vaksinasi berlangsung sesuai protokol kesehatan. Peserta tetap di himbau agar tetap disiplin dalam menerapkan protokol kesehatan 4M (memakai masker, menjaga jarak, menghindari kerumunan dan mencuci tangan). Serangkain kegiatan vaksin yang sudah diterapkan merupakan suatu upaya agar seluruh tenaga pendidik tetap sehat dan terhindar dari paparan COVID-19 serta dapat melakukan pembelajaran tatap muka kembali dengan aman.

Kegiatan pengabdian masyarakat ini sangat memiliki pengaruh yang sangat baik dan menguntungkan untuk ITKES Muhammadiyah Sidrap Selaku mitra di kegiatan ini. Pelaksanaan vaksinasi serentak yang dilakukan juga memudahkan mahasiswa untuk mendapat pelayanan vaksin sebagai persiapan untuk pembelajaran tatap muka secara mudah, cepat dan gratis.

Kegiatan edukasi yang berisi informasi sedang berlangsung program vaksinasi COVID-19 yang digalakkan oleh pemerintah Indonesia. Informasi yang disampaikan adalah tujuan dari vaksinasi ini adalah agar terciptanya kekebalan atau imunitas tubuh terhadap paparan virus corona. Tujuan berikut dari vaksinasi adalah agar terciptanya kekebalan komunitas dari seluruh warga terhadap virus corona. Harapan akhir dari program vaksinasi adalah berakhirnya pandemi global yang disebabkan oleh virus corona (Jaya, dkk., 2021).

Informasi yang diberikan kepada masyarakat terkait vaksin yang digunakan adalah bahwa vaksin COVID-19 telah aman digunakan oleh masyarakat. Proses pengujian keamanan dan keefektifan vaksin COVID-19 telah selesai dilakukan di Indonesia denga hasil yang baik. Keamanan vaksin ditegaskan dengan dikeluarkannya Emergency Use Authorization (EUA) oleh Badan Pengawas Obat Dan Makanan Republik Indonesia (BPOM RI)

Pengetahuan masyarakat Indonesia secara umum akan vaksin COVID-19 dipengaruhi oleh usia, tingkat pendidikan dan jenis pekerjaan. Masyarakat Indonesia dengan usia diatas 30 tahun memiliki pengetahuan yang lebih baik akan vaksin COVID-19 dibandingkan masyarakat dengan usia yang lebih muda. Tingkat pendidikan masyarakat yang semakin tinggi juga meningkatkan pengetahuan dan pemahaman masyarakat akan informasi vaksin COVID-19. Penelitian ini dilakukan pada tahun 2021 terhadap 816 responden yang tersebar dari berbagai daerah di Indonesia (Sulistyawati, et al., 2021).

Program vaksinasi COVID-19 dimulai pada tanggal 13 Januari 2021. Jenis Vaksin yang telah digunakan di Indonesia adalah AstraZeneca, Moderna, Pfizer, Sinopharm dan Sinovac (Kemenkes, RI, 2020). Kelima vaksin tersebut memiliki efek yang berbeda- beda. Pemerintah Indonesia sampai April 2021 menargetkan 40,3 juta orang sudah tervaksin dengan dosis lengkap (dua kali dosis penyuntikan). Tiga jenis vaksin yaitu Sinovac, AstraZeneca dan Sinopharm sudah digunakan di Indonesia, tetapi pencapaian pemberian vaksin sampai akhir April 2021 hanya mencapai 19\% dari target (Satuan Tugas Penanganan COVID-19, 2021).

\section{KESIMPULAN}

Kegiatan sosialisasi dan vaksinasi semua peserta antusias dan merasakan manfaatnya. Adapun yang mengalami efek samping ringan dan telah selesai masa pemantauan. Proses kegiatan diawali dengan sosialisasi, pelaksanaan vaksinasi Covid - 19 dengan jenis Sinovac dan Moderna. Pelaksanaan vaksinasi tahap 1 dan tahap 2 berjalan dengan baik dan lancar. Hasil daripada program vaksinasi ini adalah bahwa Tenaga Pendidik dan kependidikan sebagai salah satu penggerak kemajuan suatu bangsa telah dipersiapkan terlebih dahulu untuk kembali mengadakan pembelajaran tatap muka sesuai dengan anjuran pemerintah. Kekurangan dari kegiatan ini adalah tidak dilakukannya pemberian masker secara gratis. Selanjutnya kegiatan pengembangan akan dilakukan di lingkup ITKES Muhammadiyah Sidrap sebagai role model 
untuk publik untuk mendukung program pemerintah dalam memutus mata rantai penyebaran COVID-19.

\section{UCAPAN TERIMA KASIH}

Ucapan terima kasih kami sampaikan kepada pihak Rektor ITKES Muhammadiyah Sidrap, Gugus COVID-19 Kabupaten Sidrap, Lembaga Penelitian dan Pengabdian Masyarakat ITKES Muhammadiyah Sidrap, serta pihak Puskesmas Pangkajene Kabupaten Sidrap yang telah memberikan bantuan sehingga kegiatan pengabdian masyarakat ini dapat terlaksana dengan baik.

\section{DAFTAR PUSTAKA}

Astuti, N. P., Nugroho, E. G. Z., Lattu, J. C., Potempu, I. R., \& Swandana, D. A. (2021). Persepsi Masyarakat terhadap Penerimaan Vaksinasi COVID-19: Literature Review. Jurnal Keperawatan, 13(3), 569-580.

Dewi, W. A. F. (2020). Dampak COVID-19 terhadap implementasi pembelajaran daring di Sekolah Dasar. Edukatif: Jurnal Ilmu Pendidikan, 2(1), 55-61.

Edy, H. J., \& Suoth, E. J. (2021). Edukasi Pentingnya Vaksinasi COVID-19 Melalui Program Kemitraan Masyarakat Pada Kolom 13 GMIM Siloam. The Studies of Social Sciences, 3(2), 30 35. file:///C:/Users/asus/Downloads/36119-76794-2-PB.pdf

Firman, F., \& Rahayu, S. (2020). Pembelajaran online di tengah pandemi COVID-19. Indonesian Journal of Educational Science (IJES), 2(2), 81-89.

Lamirin, L., Nuriani, N., Sentosa, H., \& Liana, L. (2021). Sosialisasi Dan Vaksinasi COVID-19 Kepada Tenaga Pendidik Serta Kependidikan Di Perguruan Buddhis Bodhicitta Medan.Jurnal Pengabdian Kepada Masyarakat Bodhi Dharma,1(1), 21-28. https://bodhidharma.e-journal.id/JPMB/article/view/28/26

Nurdiana, A., Marlina, R., \& Adityasning, W. (2021). Berantas Hoax Seputar Vaksin CoVID-19 Melalui Kegiatan Edukasi dan Sosialisasi Vaksin COVID-19. ABDIMAS: Jurnal Pengabdian Masyarakat, 4(1), 489-495 http://umtas.ac.id/journal/index.php/ABDIMAS/article/view/1175/624

Sulistyawati, S., Rokhmayanti, R., Aji, B., Wijayanti, S. P. M., Hastuti, S. K. W., Sukesi, T. W., \& Mulasari, S. A. (2021). Knowledge, attitudes, practices and information needs during the COVID-19 pandemic in indonesia. Risk Management and Healthcare Policy, 14, 163. https://www.ncbi.nlm.nih.gov/pmc/articles/PMC7814231/

Yulita, W. (2021). Analisis Sentimen Terhadap Opini Masyarakat Tentang Vaksin COVID-19 Menggunakan Algoritma Naïve Bayes Classifier.Jurnal Data Mining dan Sistem Informasi, 2(2),

$1-9$.

https://ejurnal.teknokrat.ac.id/index.php/JDMSI/article/view/1344/672 


\section{Halaman Ini Dikosongkan}

